\title{
IMPLEMENTASI PEMBELAJARAN SEJARAH KEBUDAYAAN ISLAM PADA MADRASAH TINGKAT DASAR DI KABUPATEN PASURUAN
}

\author{
Amang Fathurrohman, Mohammad Yusuf Wijaya, Endang Tyasmaning, Hufron, Alfian Adi \\ Saputra, Muhammad Holimi, Priatmojo Suryo Kuncoro, Fatmah K \\ IAI Sunan Kalijogo Malang, \\ amangfr@gmail.com,yusufwijaya.iaiskj@gmail.com,etyasmaning@gmail.com, bufron.iaiskj@gmail.com, \\ alfian.iaisk.j@gmail.com, halimi15@gmail.com,kuncoro.iaiskj@gmail.com,fatmabk01@gmail.com
}

\begin{abstract}
Islamic Cultural History Lessons have been studied at Madrasab Ibtidaiyah (MI) and Madrasab Tsanawiyah (MTs) in Indonesia. Using a qualitative method, which was sourced from $15 \mathrm{MI}$ and MTs institutions taken randomly in 4 sub-districts in

Received: Pasuruan Regency. The results of this study indicate that many Islamic Cultural March $19^{\text {th }} 2020$ History Lessons Teachers still use lecture and discussion methods. Media often used are books and student worksheets. Teachers' problems in teaching media and learning facilities are limited, especially the availability of LCDs and access to Islamic History videos that are relevant to the subject matter. The learning process that relies heavily on the lecture method has implications for students who are bored and have difficulty understanding Islamic Cultural History subject matter. The solutions used include reviewing it repeatedly, providing motivation and innovating learning about Islamic Cultural History.

Accepted:

May $03^{\text {th }} 2020$

Keywords:

Islamic Cultural History, Madrasah Ibtidaiyah, Madrasah Tsanawiyah
\end{abstract}

\section{PENDAHULUAN}

Mata pelajaran Sejarah memiliki peran strategis dalam pembentukan watak dan peradaban bangsa yang bermartabat serta memupuk rasa kebangsaan dan cinta tanah air. Dengan mempelajari sejarah, peserta didik akan dapat melakukan kajian tentang apa, mengapa, bagaimana, serta akibat apa yang timbul dari jawaban masyarakat bangsa di masa lampau tersebut terhadap tantangan yang dihadapi bagi kehidupan pada masa sesudah peristiwa itu dan masa kini. Pendidikan sejarah juga mengarahkan peserta didik dalam mengenal nilai-nilai bangsa yang diperjuangkan pada masa lalu, dipertahankan dan disesuaikan untuk kehidupan masa kini, dan dikembangkan lebih lanjut untuk kehidupan masa depan.

Dengan Materi sejarah, juga akan dapat memberikan informasi tentang keberhasilan dan kegagalan menghadapi berbagai persoalan bangsa. Didalamnya pasti akan diuraikan bagaimana tindakan yang dilakukan para pelaku sejarah yang tidak berhasil mencapai tujuan dan perbuatan apa yang mereka lakukan yang berhasil mencapai tujuan. Karena cerita tentang keberhasilan dan kegagalan adalah sisi kehidupan manusia yang bisa dipelajari dan diambil manfaatnya untuk diaplikasikan di masa mendatang. ${ }^{1}$

Walaupun begitu, pendidikan sejarah dalam realitasnya masih belum mendapatkan ruang yang baik. Hal ini dapat dilihat dari ragam karya ilmiah yang berbasis sejarah yang inovatif masih belum banyak

\footnotetext{
${ }^{1}$ S. Hamid Hasan, "Pendidikan Sejarah Untuk Memperkuat Pendidikan Karakter," Paramita 22, no. 1 (2012): 87-88.
} 
ditemukan, misalnya novel sejarah Islam. Mudah dipahami bahwa novel sejarah sangat sedikit jumlahnya, dan tidak begitu populer. Buku teori khusus mengenai genre sastra sejarah Islam juga masih sulit ditemukan, walaupun semua mengakui bahwa genre sastra yang menyajikan sejarah dianggap sebagai karya besar. ${ }^{2}$ Buku sejarah yang berbasis riset sejarah mendalam juga masih jarang ditemukan. Yang banyak ditemukan adalah buku teks Sejarah Islam yang bersifat umum, sehingga pengayaan informasi sejarah Islam masih perlu dikembangkan lagi. ${ }^{3}$

Lalu, bagaimana dengan pembelajaran SKI di tingkat satuan pendidikan? Apakah proses pembelajaran juga masih belum mendapat ruang yang baik dalam implementasinya?> untuk itu, maka hasil kajian ini akan mengupas bagaimana implementasi pembelajaran Sejarah Kebudayaan Islam pada satuan pendidikan dasar (MI dan MTs) diterapkan di Kabupaten Pasuruan.

\section{METODE}

Kajian ini menggunakan metode kualitatif dengan sumber data dari 15 lembaga Tingkat MI dan MTs dari 4 kecamatan. Teknik Pengumpulan Data dilakukan dengan observasi dan wawancara terhadap guru SKI tingkat MI dan MTs. Analisis data melalui pengumpulan, pemilahan dan reduksi data, serta penyajian data untuk menyajikan bagaimana implementasi pembelajara SKI pada satuan pendidikan keagamaan Islam tingkat dasar (MI-MTs) di Kabupaten Pasuruan.

\section{HASIL DAN PEMBAHASAN}

\section{Potret Pendidikan Dasar Keagamaan Islam di Kabupaten Pasuruan}

Kabupaten Pasuruan telah mentasbihkan diri sebagai Kota Santri. Salah satu indicator diantaranya banyak berdiri pondok pesantren di Kota tersebut. Kabupaten Pasuruan telah memiliki tradisi penyelenggaraan pendidikan kegamaan Islam yang sudah mengakar sejak lama dan berkembang sejak abad ke-18. Hal ini dapat dilihat dari keberadaan Pondok Pesantren Sidogiri berdiri sejak tahun 1745, dan sampai saat ini pondok pesantren tersebut menjadi salah satu pesantren besar di Indonesia yang masih eksis dan terus memberikan kontribusi dalam pengembangan pendidikan keagamaan Islam di Indonesia, khususnya di wilayah Kabupaten Pasuruan. ${ }^{4}$ Selain Pesantren Sidogiri, Kabupaten Pasuruan juga berkembang banyak pesantren lainnya yang tersebar di setiap kecamatan dan desa, serta lembaga pendidikan Islam lainnya, sebagaimana tersaji dalam data jumlah lembaga pendidikan Islam berikut ini: ${ }^{5}$

\footnotetext{
2 Apsanti Djokosujatno, "Novel Sejarah Indonesia: Konvensi, Bentuk, Warna, Dan Pengarangnya," Makara, Sosial Humaniora 6, no. 1 (2002): 14-15.

${ }^{3}$ Lihat kupasan dari Edwar Djamaris, Menggali Khazanah Sastra Melayu Klasike (Sastra Indonesia Lama), Kedua. (Jakarta: Balai Pustaka, 1993). Dalam buku ini disebutkan bahwa buku penelitian tentang genre sastra sejarah di Indonesia khususnya masa klasik masih sangat sulit ditemukan.

${ }^{4}$ Lihat situs resmi Pondok Pesantren Sidogiri dalam "Sejarah Sidogiri," Sidogiri.Net.

${ }^{5}$ Fathurrohman Amang, "Studi Kebijakan Sinergi Pendidikan Keagamaan Islam Dan Pendidikan Umum Di Kabupaten Pasuruan” (UIN Sunan Ampel Surabaya, 2019).
} 
Tabel 1. Lembaga Pendidikan Islam di Kabupaten Pasuruan

\begin{tabular}{|l|l|r|r|r|}
\hline No & \multicolumn{1}{|c|}{ Jenjang } & \multicolumn{1}{c|}{ Lembaga } & \multicolumn{1}{c|}{ Guru } & \multicolumn{1}{c|}{ Siswa } \\
\hline 1 & RABATA & 380 & 1.441 & 14.668 \\
\hline 2 & Madrasah Ibtidaiyah & 288 & 3.294 & 29.529 \\
\hline 3 & Madrasah Tsanawiyah & 145 & 3.055 & 22.272 \\
\hline 4 & Madrasah Aliyah & 63 & 1.5 & 10.122 \\
\hline 5 & Madrasah Diniyah/Pondok Pesantren & 1.239 & 11.134 & 118.336 \\
\hline 6 & TPQ & 1.269 & 6.913 & 88.142 \\
\hline & Jumlah & $\mathbf{3 . 3 8 4}$ & $\mathbf{2 7 . 3 3 4}$ & $\mathbf{2 8 3 . 0 6 9}$ \\
\hline
\end{tabular}

Dari table di atas, diketahui bahwa pendidikan keagamaan Islam tingkat Dasar cukup besar dengan rincian MI mencapai 288 lembaga dengan jumlah siswa 29.525 dan MTs mencapai 145 lembaga dengan jumlah siswa 22.272 di Tahun 2013.

\section{Metode dan Media dalam Pembelajaran SKI}

Dalam proses pembelajaran, beragam metode telah digunakan oleh Guru MI-MTs di Kabupaten Pasuruan untuk menyampaikan materi SKI. Hasil studi lapangan menunjukkan bahwa Ceramah dan diskusi Diskusi masih menjadi pilihan utama guru SKI, sebagaimana tersaji dalam grafik berikut:

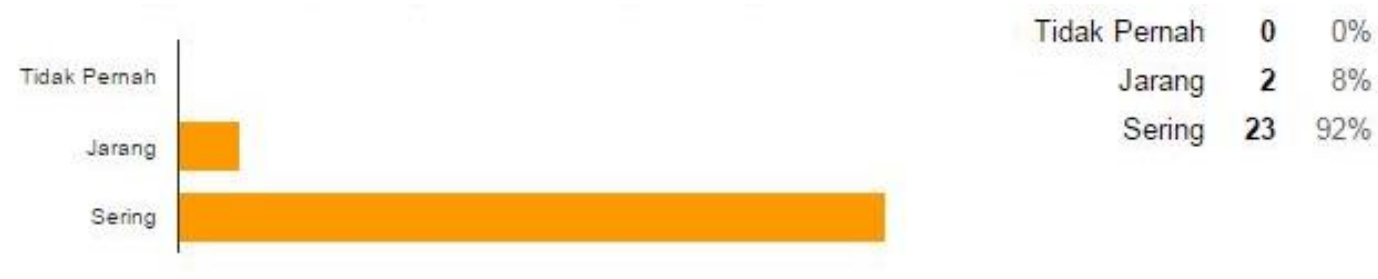

Grafik 1. Metode Ceramah Pembelajaran SKI

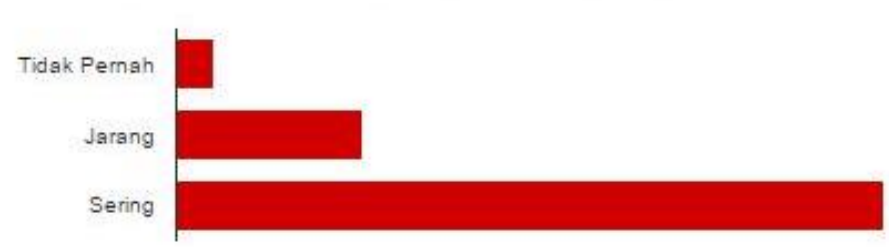

$\begin{array}{rrr}\text { Tidak Pernah } & 1 & 4 \% \\ \text { Jarang } & 5 & 20 \% \\ \text { Sering } & 19 & 76 \%\end{array}$

Grafik 2. Metode Diskusi dalam Pembelajaran SKI

Dari Grafik 1 dan 2 di atas menunjukkan bahwa ceramah digunakan 92\% oleh Guru MI dan MTs, dilanjutkan dengan diskusi sebesar $76 \%$. Selain itu, pendekatan yang masih menjadi favorite para guru adalah memberikan tugas review / resume buku yang mencapai 43,5\%, sebagaimana tersaji pada grafik 3 berikut ini 

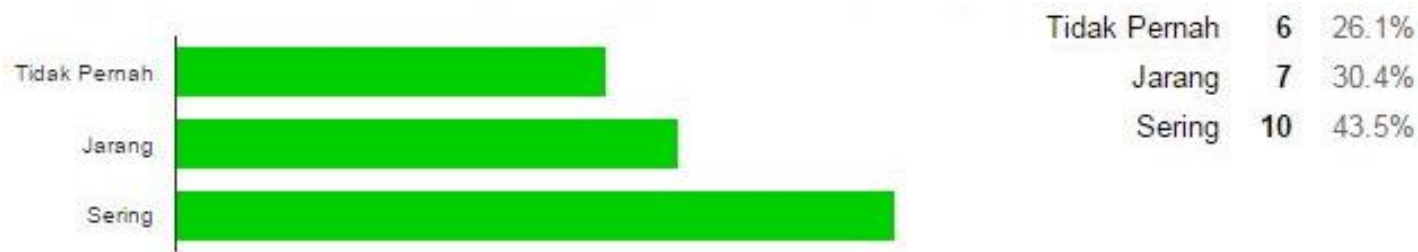

Grafik 3. Review / Resume Buku Materi SKI

Selain metode di atas, para guru juga menggunakan beragam metode lainnya, seperti Presentasi, Drama Sejarah, atau penelitian sejarah dengan berkunjung ke situs para tokoh sejarah Islam. Namun, metode tersebut tidak sering digunakan oleh para Guru MI-MTs di Kabupaten Pasuruan, sebagaimana tersaji dalam grafik berikut:

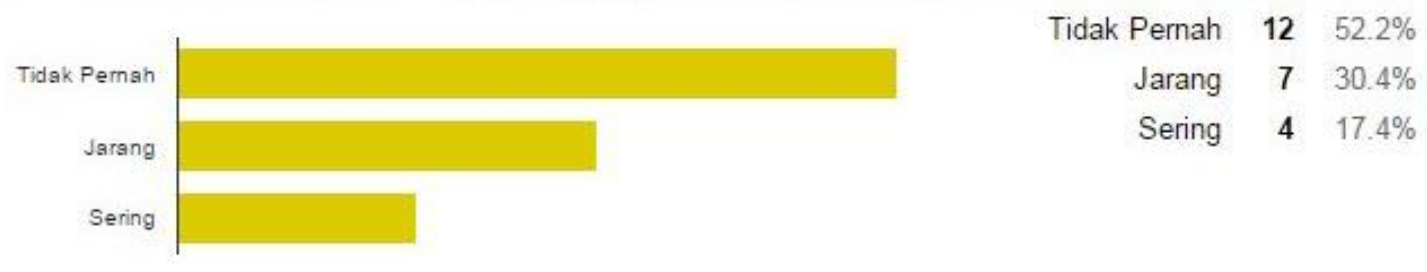

Grafik 4. Presentasi Pelajaran SKI

Dari grafik 4 di atas terlihat bahwa sebagian besar guru (52,2\%) tidak menggunakan presentasi dalam proses pembelajaran SKI. Hal ini karena para siswa yang dianggap masih cukup berat kemampuan mereka untuk melakukan presentasi materi SKI, karena masih di level MI dan MTs. Namun ada juga guru yang sering $(17,4 \%)$ dan sesekali menggunakan pendekatan presentasi ini $(30,4 \%)$ karena mereka menilai bahwa anak didik mereka telah mampu secara mandiri untuk melakukan presentasi materi SKI, khususnya siswa MTs.

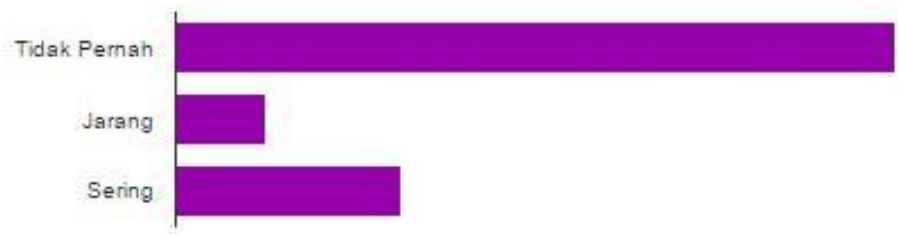

$\begin{array}{rrr}\text { Tidak Pernah } & \mathbf{1 6} & 69.6 \% \\ \text { Jarang } & \mathbf{2} & 8.7 \% \\ \text { Sering } & \mathbf{5} & 21.7 \%\end{array}$

Grafik 5. Drama Sejarab Islam

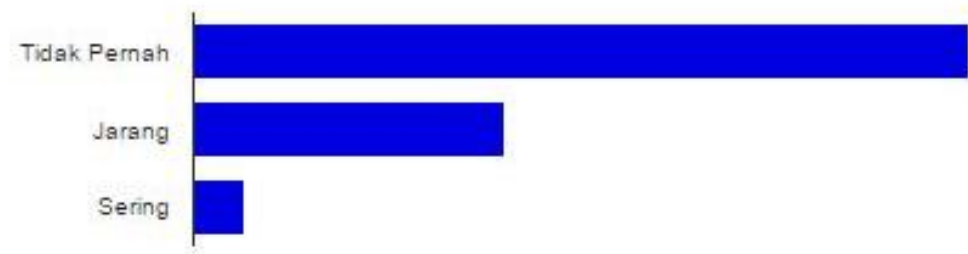

$\begin{array}{rrr}\text { Tidak Pernah } & 15 & 68.2 \% \\ \text { Jarang } & 6 & 27.3 \% \\ \text { Sering } & 1 & 4.5 \%\end{array}$

Grafik 6. Penelitian Sejarah Islam 
Guru SKI Tingkat MI-MTs di Kabupaten Pasuruan memanfaatkan drama dan penelitian sejarah dalam proses pembelajaran SKI di sekolah mereka. Walaupun yang menggunakan metode ini tidak banyak, yakni 69,6\% menyatakan tidak pernah menggunakan metode drama dan 68,2\% tidak pernah menggunakan penelitian sejarah, namun para guru SKI sebagian guru $(21,7 \%)$ masih memanfaatkan drama sebagai metode yang digunakan agar kelas menjadi hidup. Sedangkan untuk penelitian sesekali digunakan oleh guru SKI (27,3\%) dengan mengajak anak-anak mereka melakukan kunjungan situs bersejarah para tokoh Islam, misalnya melalui riblah ilmiah Wali Songo.

Dilihat dari media yang digunakan, Guru SKI MI dan MTs di Kabupaten Pasuruan telah cukup beragam, mulai dari akses internet, buku SKI, Lembar Kerja Siswa (LKS) dan media lainnya sebagaimana tersaji pada grafik berikut:

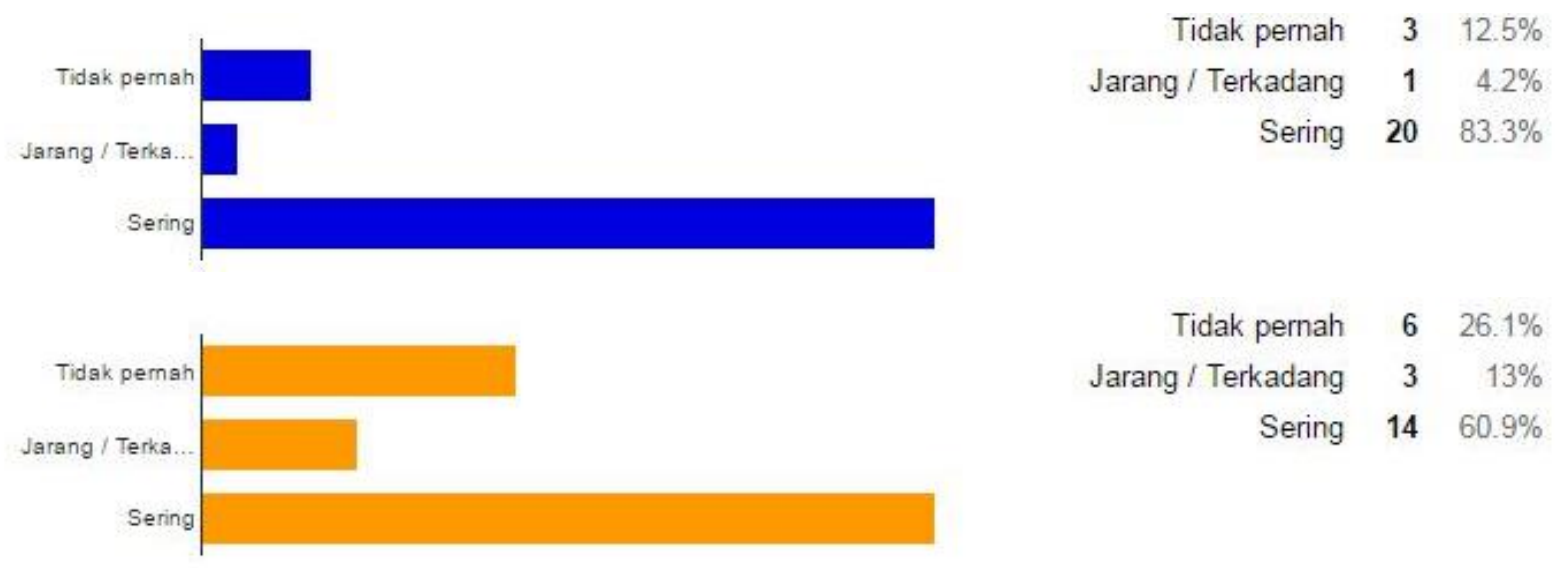

Grafik 7. Penggunaan Buku (Atas) dan LKS (Bawah) dalam pembelajaran SKI

Buku dan LKS menjadi media utama dalam pembelajaran SKI di tingkat MI dan MTs. Hal ini terlihat dari Grafik 7 di atas yang menyatakan bahwa 83,3\% guru sering menggunakan buku SKI dan 60,9\% sering menggunakan LKS sebagai media dalam belajar SKI bagi siswa-siswi mereka.

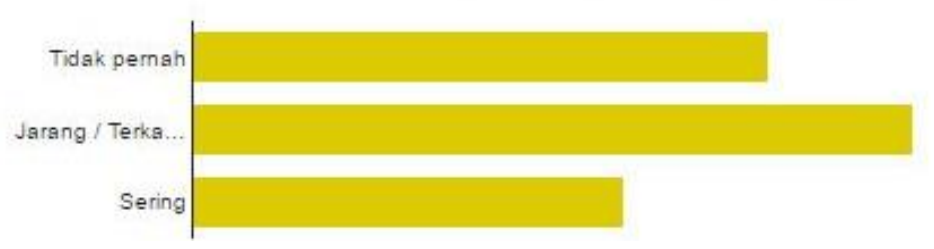

$\begin{array}{rrr}\text { Tidak pernah } & \mathbf{8} & 33.3 \% \\ \text { Jarang/ Terkadang } & \mathbf{1 0} & 41.7 \% \\ \text { Sering } & \mathbf{6} & 25 \%\end{array}$

Grafik 8. Penggunaan Gambar dalam pembelajaran SKI

Penggunaan gambar sebagai media belajar juga masih cukup favorit digunakan oleh Guru SKI MI dan MTs di Kabupaten Pasuruan. Sebanyak besar mereka menyatakan sering menggunakan media gambar $(25 \%)$ dan 41,7\% menyatakan terkadang menggunakan media gambar. Suasana belajar yang menyenangkan juga dilakukan oleh Guru MI dan MTs dengan mengajak anak-anak mereka belajar SKI di Perustakaan sebagaimana tersaji di grafik 9 di bawah ini. 


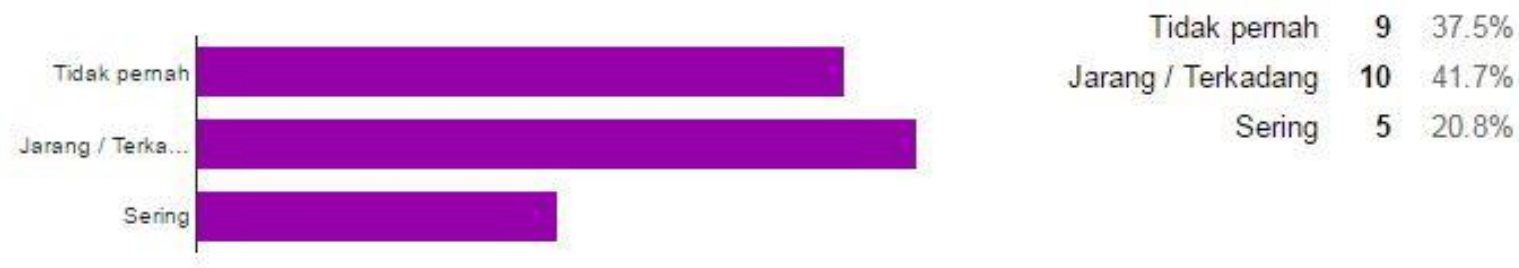

\section{Grafik 8. Belajar SKI di Perustakaan Sekolah}

Media belajar melalui internet dan film sejarah Islam juga dimanfaatkan oleh Guru SKI MI-MTs di Kabupaten Pasuruan. Walaupun hanya sebagian kecil saja yang sering memanfaatkan media belajar di internet dan film sejarah Islam (16,7\%) namun mereka telah berusaha untuk terus berinovasi agar dalam proses belajar mengajar SKI menjadi lebih variatif dan menyenangkan.
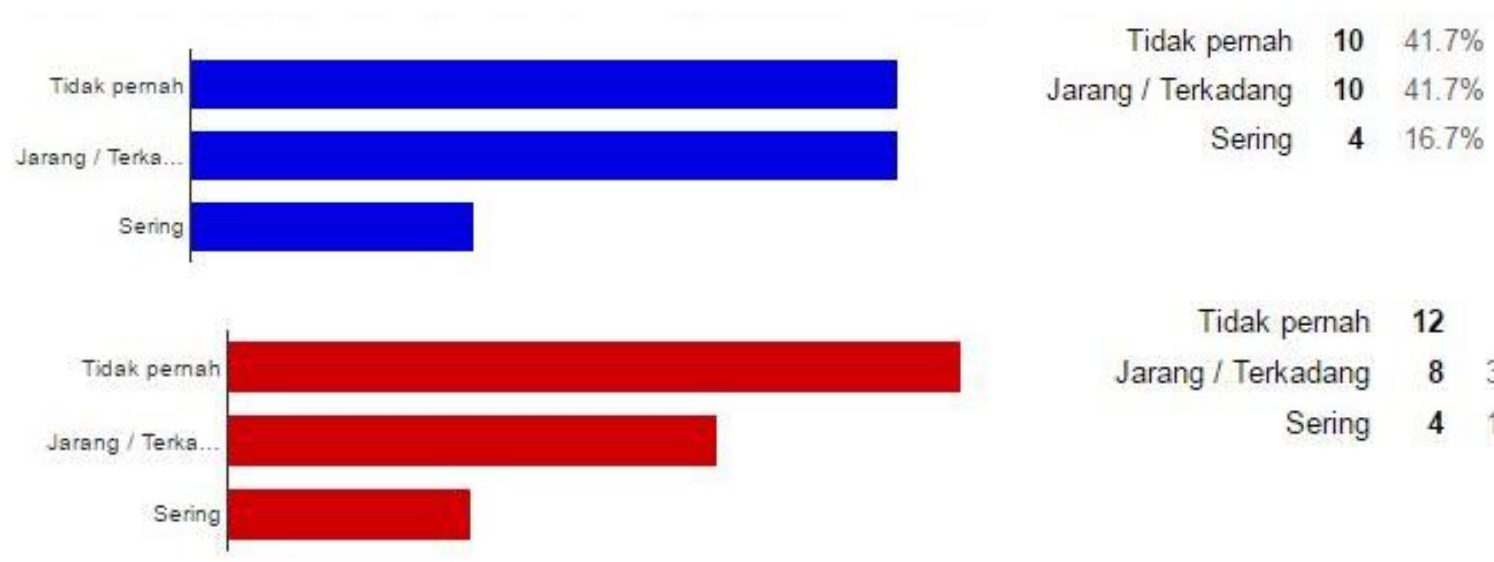

Grafik 9. Penggunaan Internet (Atas) dan Film Sejarab Islam (Bawah) dalam Materi SKI

\section{Problem dan Solusi yang digunakan dalam Pembelajaran SKI}

Problem pembelajaran SKI tingkat MI-MTs di Kabupaten Pasuruan pada umumnya dapat dikategorikan pada problem pada media ajar, sumber ajar, dan proses pembelajaran. Pada media ajar dan sumber ajar, para Guru MI menyatakan bahwa keterbatasan sarana prasarana di MI-MTs seperti ketersediaan LCD yang terbatas atau belum tersedia, cukup menyulitkan bagi para Guru MI untuk menyampaikan materi SKI pada siswa-siswi mereka. Selain itu, Video Sejarah Islam yang sesuai dengan materi yang dibutuhkan belum banyak tersebar di internat juga menjadi kendala bagi mereka untuk memanfaatkan Video SKI dalam proses pembelajaran mereka. Sehingga, buku materi dan LKS masih menjadi 'primadona' sumber ajar SKI yang digunakan oleh guru.

Hal ini berdampak kepada proses pembelajaran yang dirasakan oleh para Guru SKI tingkat MIMTs yang menyatakan bahwa para siswa mereka sulit untuk menghafalkan materi SKI, baik menghafal tahun-tahun sejarah, nama-nama tokoh sejarah, serta kebanyakan anak-anak kurang minat dan bosan terhadap pelajaran SKI, karena guru cenderung menggunakan ceramah dalam penyampaian materinya. 
Kemampuan yang beragam dari para siswa juga menyulitkan para guru MI-MTs, sehingga para Guru SKI dituntut lebih kreatif dalam menyampaikan materi SKI dengan segala keterbatasan yang dihadapinya.

Beberapa solusi yang digunakan oleh Guru SKI di MI-MTs dalam kontek sumber ajar adalah para guru berusaha untuk mencari dan mengakses video sejarah Islam, baik di internet maupun di VCD/LCD yang relevan dengan materi mereka.

Dalam proses belajar mengajar, inovasi dan motivasi seringkali diselipkan dalam materi yang disampaikan oleh mereka, sehingga anak-anak tetap semangat dan memiliki inspirasi dari para tokohtokoh yang akan berguna bagi kehidupan mereka. Misalnya dengan menceritakan semangat belajar tokohtokoh Islam terdaulu. Selain itu, para guru seringkali menggunakan pendekatan membaca dan penyampaian secara berulang-ulang, penugasan dan penulisan materi SKI, serta menghafalkan tokoh dan kapan sejarah itu terjadi masih menjadi pendekatan favorite guru MI-MTs. Namun begitu, Guru MI-MTs juga mengembangkan pendekatan dengan cara diskusi, belajar kelompok, tanya jawab serta mengajak anak-anak ke tempat sejarahnya supaya banyak yang berminat dengan sejarah, misalnya melalui agenda Riblah Ilmiah pada situs sejarah Islam, diantaranya ke Walisongo.

\section{Pembahasan}

Pembelajaran SKI pada umumnya masih menggunakan metode ceramah, sehingga siswa menjadi kurang kreatif dan kegiatan pembelajaran hanya berlangsung satu arah yang menyebabkan siswa menjadi pasif dan hanya memperhatikan guru. Para siswa juga terlihat bosan dan jenuh selama mengikuti proses pembelajaran dan guru cenderung menguasai kelas sehingga siswa enggan untuk bertanya dan kurang leluasa untuk menyampaikan ide-idenya. Kondisi ini juga terlihat dari hasil studi lapangan di Kabupaten Pasuruan dan sejalan dari kajian yang dilakukan oleh Dini Fitria dan Johan Andriesgo di Madrasah Tsanawiyah PP. Nurul Islam Kampung Baru Riau, ${ }^{6}$ maupun kajian Umi Mahmudah di MTsN Salatiga. ${ }^{7}$

Oleh karena itu, maka guru harus dituntut memiliki inovasi yang baik dalam pembelajaran SKI, diantaranya melalui scramble maupun pendekatan lainnya. Hasil kajian Dini Fitria dan Johan Andriesgo menyatakan bahwa penguasaan pembelajaran SKI pada awalnya masib 39,13\%. Dengan pendekatan yang menarik melalui scramble berbasis power point, hasil kajian dengan metode action learning didapatkan hasil siklus pertama meningkat menjadi 65,22\%, dan siklus kedua bari bisa mencapai 95,65\% untuk mampu menguasai pembelajaran SKI dengan menggunakan Scramble Berbasis Powerpoint pada materi SKI. ${ }^{8}$ Hal ini menunjukkan bahwa penggunaan pendekatan yang inovatif mampu meningkatkan penguasaan materi,

\footnotetext{
${ }^{6}$ Dini Fitria and Johan Andriesgo, "Penerapan Model Pembelajaran Scramble Berbasis Powerpoint Untuk Meningkatkan Hasil Belajar Siswa Pada Bidang Studi Sejarah Kebudayaan Islam," J-P AI: Jurnal Pendidikan Agama Islam 5 , no. 2 (2019): 87-92.

${ }^{7}$ Umi Mahmudah, "Problematika Pembelajaran Sejarah Kebudayaan Islam, Pada Siswa MTS Negeri Salatiga Tahun 2017” (Salatiga: IAIN SALATIGA, 2017), http://e-repository.perpus.iainsalatiga.ac.id/2221/1/Umi Mahmudah.pdf.

${ }^{8}$ Fitria and Andriesgo, "Penerapan Model Pembelajaran Scramble Berbasis Powerpoint Untuk Meningkatkan Hasil Belajar Siswa Pada Bidang Studi Sejarah Kebudayaan Islam."
} 
namun masih membutuhkan proses yang tidak mudah. Hal ini tentu akan lebih maksimal apabila dilakukan dengan perencanaan dan persiapan pembelajaran yang baik dan matang. ${ }^{9}$

\section{KESIMPULAN}

Sejarah Kebudaya Islam adalah salah satu mata pelajaran yang sudah diberikan di Madrasah tingkat dasar, yakni Madrasah Ibtidaiyah dan Madrasah Tsanawiyah. Hasil kajian ini menunjukkan bahwa ceramah dan diskusi masih menjadi metode pembelajaran yang sering digunakan oleh Guru SKI. Sedangkan buku dan LKS adalah media favorite para Guru SKI tingkat MI-MTs di Kabupaten Pasuruan. Problem pada media ajar, sumber ajar yang terbatas, khususnya ketersediaan LCD dan akses video SKI yang relavan dengan materi yang dibutuhkan oleh Guru SKI, serta proses pembelajaran yang banyak bertumpu pada metode ceramah, sehingga anak-anak merasa bosan dan sulit memahami dan menghafalkan tahun dan tokoh-tokoh sentral dalam materi SKI. Solusi yang digunakan oleh guru diantaranya dengan melakukan kajian secara berulang-ulang, memberikan motivasi dengan mengambil nilai yang terkadnung dalam materi SKI serta anak-anak diajak untuk eksplorasi SKI dengan agenda rihlah ilmiah pada situs sejarah Islam.

\section{DAFTAR PUSTAKA}

Aldjufri, H. Jusbakir. Kepemimpinan Negarawan: Otonomi Daerab Mewujudkan Pembangunan Berbasis Kompetensi Lokal. Malang: The HQ Center, 2004.

Amang, Fathurrohman. "Studi Kebijakan Sinergi Pendidikan Keagamaan Islam Dan Pendidikan Umum Di Kabupaten Pasuruan.” UIN Sunan Ampel Surabaya, 2019.

Badan Pusat Statistik Kabupaten Pasuruan. Kabupaten Pasuruan Dalam Angka 2016. Kabupaten Pasuruan, 2016.

Djamaris, Edwar. Menggali Khazanah Sastra Melayu Klasike (Sastra Indonesia Lama). Kedua. Jakarta: Balai Pustaka, 1993.

Djokosujatno, Apsanti. "Novel Sejarah Indonesia: Konvensi, Bentuk, Warna, Dan Pengarangnya.” Makara, Sosial Humaniora 6, no. 1 (2002): 14-15.

Fathurrohman, Amang, and Moh. Nurhadi. "Perencanaan Pembelajaran Guru Sekolah Dasar Dalam Materi Pendidikan Agama Islam Di Kabupaten Pasuruan.” Jurnal Ilmu Tarbiyab "At-Tajdid” 5, no. 2 (2016): 219-242.

Fitria, Dini, and Johan Andriesgo. "Penerapan Model Pembelajaran Scramble Berbasis Powerpoint Untuk Meningkatkan Hasil Belajar Siswa Pada Bidang Studi Sejarah Kebudayaan Islam.” J-PAI: Jurnal Pendidikan Agama Islam 5, no. 2 (2019): 87-92.

${ }_{9}$ Amang Fathurrohman and Moh. Nurhadi, "Perencanaan Pembelajaran Guru Sekolah Dasar Dalam Materi Pendidikan Agama Islam Di Kabupaten Pasuruan," Jurnal Ilmu Tarbiyah “At-Tajdid” 5, no. 2 (2016): 219-242. 
Hasan, S. Hamid. "Pendidikan Sejarah Untuk Memperkuat Pendidikan Karakter.” Paramita 22, no. 1 (2012): 87-88.

Mahmudah, Umi. "Problematika Pembelajaran Sejarah Kebudayaan Islam, Pada Siswa MTS Negeri Salatiga Tahun 2017.” Salatiga: IAIN SALATIGA, 2017. http://erepository.perpus.iainsalatiga.ac.id/2221/1/Umi Mahmudah.pdf.

"Sejarah Sidogiri." Sidogiri.Net. 